\title{
Genetic Variation Study within (Ompok bimaculatus \& Clupisoma sinensis) Populations in Samarra Dam Middle of Iraq and Shatt Al-Arab Southern of Iraq belonging to Tigris River Using Mitochondrial Cytochrome b Gene
}

\author{
Rabeeha Mankhi Jebur ${ }^{1, *}$ (iD \\ ${ }^{1}$ Basrah University, Marine Science Centre, Basrah, Iraq.
}

\section{Article History}

Received September 16, 2019

Accepted December 7, 2019

First Online December 11, 2019

\section{Corresponding Author \\ Tel.: +9647740164755 \\ E-mail: \\ raabeeha.jibur@uobasrah.edu.iq}

\section{Keywords}

Genetic variation

AMOVA

Haplotype

Cytb Gene

Nucleotide diversity

\begin{abstract}
This study was specifically aimed at Genetic Variation Study Within (Ompok bimaculatus \& Clupisoma sinensis) Populations, and evaluated partial Cytb gene sequence of mtDNA for determining the genetic variation within Ompok bimaculatus \& Clupisoma sinensis populations in Samarra Dam Middle of Iraq and Shatt Al-Arab Southern of Iraq belonging to Tigris River Using Mitochondrial Cytochrome b Gene. DNA extracted from 80 specimens of the two species of interest from two stations were analyzed. The Size of gene was (amplified Cytb gene) 1,118 bp long and 1,138bp long for O. bimaculatus and C. sinensis, respectively. By using Software DnaSP v5.1, the study revealed that there are two individual species in Samarra Dam and 3 in Shatt-AlArab river whereas 2 haplotypes in C. sinensis population in Shatt Al-Arab and only one hap. In Samarra Dam, there is also Sequencing of Cytb fragments. According to the molecular variance analysis, analyzes of nucleotide diversity and haplotypes pattern were performed separately for each community using the DnaSP v5.10 program. The analysis revealed that there are two types of specific haplotypes in (O. bimaculatus) in the Samarra Dam and 3 of the haplotypes patterns observed in the Shatt al-Arab River, while there are two haplotypes patterns in (St. Sinensis) in the Shatt al-Arab and 1 of haplotypes in Samarra Dam. Low range values of nucleotide and haplotype diversity for both species in Shatt Al-Arab river populations were revealed which refer to low genetic variation within each population in Shatt Al-Arab. As well as low range values of $\pi$ and $\mathrm{Hd}$ for (O. bimaculatus) species in Samarra Dam populations which revealed low genetic variation while no genetic variation in (C. sinensis) population.
\end{abstract}

\section{Introduction}

A genetic variation in a society describes the presence of different alleles, or alternative forms, in that group of genes. The presence of genetic variation means that individuals in the population differ in their alleles, which means that individuals differ in their genetic makeup. Local genetics in which multiple alleles are present is described as polymorphic. Allen is an alternative version or form of a gene or chromosome site (usually a group of genes). The gene has at least two or two alternative forms. Sometimes alleles containing variations in the genetic code may produce different acetates (skin or eye color). However, many differences lead to little or no apparent difference. Humans, for example, are polymorphic to features such as eye color and blood type. Genetic variation is one of the more general aspects of the concept of phenotypic variation. 
Phenotypic variation describes differences in the characteristics of individuals of the population. Variation of phenomena is of interest to biologists because of what it is natural selection: different types of phenol may have different fitness, and selection leads to the emergence of proven phenotypes leaving more descendants.

Gene variation is the process that combines two or more groups of ancestors in which independent genetic changes (mutations) accumulate and over time after they have become populations repeatedly isolated for a period of time. In some cases, subpopulations live in oceanic environments that are ecologically distinct. This may show genetic variation from the rest of the population, especially in very large populations. Whereas, genetic differences between different populations can involve mutations (which do not affect the outward shape) or increase the importance of morphological or even physiological changes. It will also accompany genetic variation that will always accompany reproductive isolation, either because of these new adaptations by definition or because of genetic drift, which is the main mechanism behind that belonging (Lars Feuk et al., 2006).

Also, genetic variation among individuals within a population can be defined at different levels. Genetic variation can be defined by observing variations in the apparent pattern of quantitative traits (constantly changing traits that are coded by many genes such as dog length or separate traits, traits that fall into separate categories and are coded by a gene or number). A few genes like white, red or pink in the petals of some flowers (Pavlopoulos et al., 2-13).

Phenotypic variation arises from either of two sources: genetic variation and environmental variation. However, only differences that arise from genetic variation can be passed on to future generations. Moreover, only a fraction of the genetic component varies, the additional genetic variation, is actually hereditary (Helena, 1989).

The added genetic variance divided by the total phenotypic variance results in heredity, which describes the amount of offspring that resemble their parents. In the 1960s, there was considerable controversy over the amount of genetic variation already present in the population, and the prevailing view was that polymorphic sites were somewhat rare. Thereafter, the development of gel electrophoresis technology allowed biologists to study patterns of protein variation in populations and determine genetic variation. Biologists have discovered surprisingly large amounts of genetic variation. In most vertebrate species, for example, approximately 30 percent of genes are found to be polymorphic (Robert, 1997).

Studies conducted in the 1970 s showed that genetic variation occurs at approximately the same levels as in other animal species. Studies in humans have also revealed that it is known that the alleged human species are not real biological groups. It has been found that there is a much greater genetic variation within races among them. Since then the absence of genetic variation has been considered anomalous. The absence of genetic variation in population groups indicates a bottleneck in the group's recent history, at which time the size of the population has become very small. The result of the population bottleneck is that all members of the current community come from a small number of individuals and therefore have only limited genetic variation. Genetic variation is expected to accumulate over time in these groups when new mutations occur (Futoyama, 1998).

The discovery of large amounts of genetic variation in almost all populations led to a different question: how is genetic variation maintained? In many cases, after all, natural selection removes genetic variation by eliminating less favorable genotypes. Many factors increase or maintain the extent of genetic variation in a community. One of these is the mutation, which is actually the ultimate source of all variations. However, mutations do not occur very often, only at a rate of approximately one mutation per 100,000 to $1,000,000$ genetic sites per generation (Gould, 1996). This rate is too slow to explain most of the shapes that appear in normal groups. However, the mutation may explain some of the very rare phenotypes that are sometimes seen, such as albinism in humans and other mammals. The second factor that contributes to genetic variation in natural populations is selective neutrality. Selective neutrality describes situations in which alternative gene alleles differ slightly in fitness. Because small differences in fitness lead to only weak natural selection, selection may be overcome by the random force of genetic drift. Alleles whose frequencies are subject to genetic drift rather than natural selection are said to be selectively neutral. Under neutrality, allele frequencies vary over time, increasing or decreasing randomly (Helena, 1989). Over long periods of time, random fluctuations in the relative frequencies of different alleles may eliminate some of them from the population. However, the genetic forms are long-term and new neutral alleles may arise constantly through the mutation. Several forms of natural selection work to preserve rather than eliminate genetic variation. These include budget selection, frequency-based selection, and changing natural selection patterns over time and velocity. Budget selection occurs when there is a heterogeneous feature in a position, a situation in which the heterozygous genotype (one involving two different alleles) is more fit than either of the two homozygous species (one of the same allele) (Futuyma, 1998). Under the heterozygote feature, all of the alleles involved in the population will be preserved.

Genetic and genetic regulations are critical to brain development and function and prevention of neurological diseases. At present, the field lacks the obvious molecular mechanisms underlying 
neuropsychiatric diseases and effective treatment options. Epigenetics provide a whole new dimension to therapeutic treatments because many of these diseases are not monogenic and are likely to have a significant environmental contribution (Roth and Sweatt, 2011; Feil and Fraga, 2012). The genome is largely influenced by environmental factors such as nutrition, chemical contaminants, painful early life experiences, temperature changes and exercise, but how it affects brain development is not well understood. More importantly, the influence of the environment on epigenetics is not limited to postpartum development, but can also affect the development of the uterus. It has recently been assumed that early life stresses that because long-term genetic changes may be caused by cellular genetic "priming". Like the immune system, once a certain environmental exposure occurs and alters the epigenetic state of the gene, that gene is now in a "moderate response" and will have a faster response if the same environmental exposure occurs again (Vineis et al., 2017). The concept of epigenetic memory in response to environmental stimuli can serve as a means of identifying individuals willing to develop neuropsychiatric diseases.

An important mechanism for regulating genes in response to tensions is non-genetic regulation, which consists of covalent modifications of DNA and histones, affecting the transcription activity of chromatin without changing the DNA sequence (Iwasaki and Paszkowski, 2014). The structure of chromatin consists of nickelosomes formed by the interaction of histone proteins with DNA, allowing the encapsulation of DNA in the nucleus (Alberts et al., 2002). Because gene expression depends on access to DNA, so the level of chromatin condensation is important for this regulation. Ichromatin can be associated with active regions of transcription, while heterochromatin is usually a textual silencing area, with hypermethyl DNA and a specific modification of histones (Vaillant and Paszkowski, 2007). Studies have highlighted three genetic markers: methylation of DNA, histone modifications and small RNAs. Important, in many cases, RNA can lead to DNA decomposition and chromatin modification (Meyer, 2015).

Epigenetic regulation can cause dynamic changes, such as the interaction of plant hypersensitivity (HR), changes in the structure of chromatin and influence on the phenotype of the plant, contributing to the adaptation of local plants to stress. Knowledge of epigenetic contributions to phenotypic plasticity and genetic variation is therefore important to understand how natural populations can adapt to different environmental conditions, especially in the context of global climate change. However, this is an area of study that clearly requests further investigation and involvement of young scientists (Vaillant and Paszkowski, 2007).
Healthy epigenetic regulations are essential for the development of normal brain function. There are many evidence suggests that their dysregulation can act as causal roles at the onset of neurological, neurodegenerative, and neuropsychological disorders. To highlight the complexity and interrelated nature of asylum regulation (Yan et al., 2011), recent studies have shown that DNA methylation and histone modification not only regulate the expression of miRNA genes but these markers are the same regulated by some miRNAs. A subset of miRNAs will affect the expression of methyl transfer DNA and histone disetylases (Sato et al., 2011). Thus, it can be conceived that, for example, ROS alteration caused by DNA methylation patterns in the nuclear genome may alter miRNA expression which in turn can affect other aspects of genetic regulation and ultimately, possibly multinational, on the phenotype of the disease. Such a complex interaction of asymptomatic regulation is not unique to mitochondrial disease (Wang et al., 2011).

Prior to the development of modern treatments, the sickle-cell disease was associated with very low fitness, since individuals usually died before reproductive age, heterozygotes, however, have normal, donut-shaped blood cells and do not suffer from sickle-cell anemia. In addition, they reveal a benefit of the sickle-cell allele, which offers protection from malaria. Consequently, heterozygous individuals have greater fitness than individuals who have two copies of the normal allele. Heterozygote advantage in this system is believed to have played a critical role in allowing a disease as harmful as sickle-cell anemia to persist in human populations. Evidence for this comes from an examination of the distribution of the sickle-cell allele, which is only found in places where malaria is a danger. Another form of natural selection that maintains genetic variation in populations is frequencydependent selection. Under frequency-dependent selection, the fitness of a genotype depends on its relative frequency within the population, with lesscommon genotypes being fit than genotypes that occur at high frequency. Frequency-dependent selection is believed to be fairly common in natural populations. For example, in situations where there is competition for resources, individuals with rare preferences may revel greater fitness than those who have more common preferences (Gould \& William, 1996).

Rivers have played a crucial role in the growth of human civilizations around the world. Humans have interacted with rivers and floodplains for thousands of years. Scientific investigations of rivers began too late. Biologists focused primarily on the study of genetic variation within populations and their relationship to the characteristics of different river habitats.

The Tigris and Euphrates, with their tributaries, form a major river system in Western Asia. From sources originating in eastern Turkey, they flow by/through Syria through Iraq into the Arabian Gulf. The system is part of 
Tigris-Euphrates ecoregion, which includes Iraq and parts of Turkey, Syria, Iran, Saudi Arabia, Kuwait, and Jordan. From their sources and upper courses in the mountains of eastern Anatolia, the rivers descend through valleys and gorges to the uplands of Syria and northern Iraq and then to the alluvial plain of central Iraq. The rivers flow in a south-easterly direction through the central plain and combine at Al-Qurnah to form the Shatt al-Arab and discharge into the Arabian Gulf. Samarra Dam is a multi-purpose barrage on the Tigris River adjacent (west) of Samarra and north of Baghdad, Iraq ("Iraqi Dam Assessments", 2012;"Electrical Power Stations in Iraq",2012).

Frequency-dependent selection may also play a role in predation: if predators form a search image for more common prey types, focusing on capturing those, less common phenotypes may revel better survival finally; changing patterns of selection over time or space can help to maintain genetic variation in a population. If selection patterns fluctuate over time, different alleles or genotypes may revel greater fitness at different times. The overall effect may be that both alleles persist in a population. Changing selection pressures over time are encountered by a species of grasshopper characterized by two color morphs, a brown morph and a green morph. earlier in the year, when the habitat is browner; the better-camouflaged brown grasshoppers enjoy greater protection from predators. Later in the season, however, the environment is greener and the green grasshoppers have higher fitness. Another possibility is that selection patterns vary from one place to another as a result of differences in habitat and environment (Patterson, 1999). The prevalence of different genotypes in different habitats, combined with gene flow between habitats, can result in the maintenance of multiple alleles in a population; one example comes from the allele for resistance to copper toxicity in species of grass. Copper-tolerant alleles are common in areas adjacent to copper mines, where the soil is contaminated (Ridley, 1993). They are not expected in un-contaminated areas, however, where they are less fit than normal alleles. Therefore, the aim of this study is to detect genetic variation between two groups of fish species in two different sites belonging to the Tigris River in Iraq using the cytochrome $B$ gene. However, due to the contamination of herb species by wind, gametes can move to large areas.

\section{The Aim of the Study}

The aim of the study is to "study genetic variation within two species of fish populations in two different locations in central and southern Iraq using mitochondrial gene".

\section{Method and Material}

The main purpose of the dam is to divert the flood waters of the Tigris River to Lake Tharthar via the Tharthar Depression along with irrigation and an $84 \mathrm{MW}$ hydroelectric power plant. It also works on hydropower production and flood control - although the latter has become less important with the construction of the Mosul Dam north of Samarra and many other large dams in Turkey. Samarra Barrage part of the structure contains 17 gates capable of transporting 7,000 cubic meters / second $(247,203 \mathrm{cu} \mathrm{ft} / \mathrm{s})$ of water to the Tigris River. The design capacity of the reservoir is $150,000,000$ cubic meters $(121,607$ acres $\bullet$ ft), but most of it is filled with sediment ("Iraqi Dam Ratings", 2012) while the Shatt al-Arab is about $200 \mathrm{~km}$ (120 mi) long, at the confluence of the Euphrates and Tigris in the town of Al-Qurnah in the province of Basra in southern Iraq. The southern end of the river forms the border between Iraq and Iran and reaches the mouth of the river as it drains into the Arabian Gulf. Its width ranges from about 232 meters (761 ft) in Basra to 800 meters (2,600 feet) in its mouth (Figure 1).

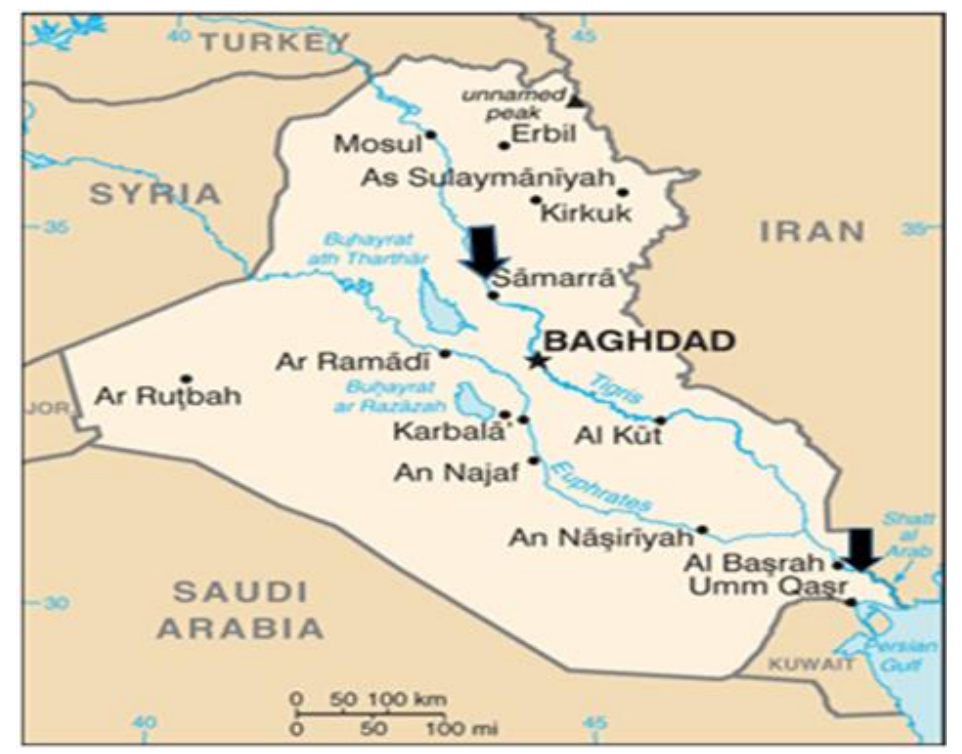

Figure 1. Locations of sampling stations on Samarra Dam middle of Iraq on Tigris river and Shatt Al-Arab southern of Iraq. 


\section{Sample Collection}

These two fish species (Ompok bimaculatus and Clupisoma sinensis) were collected from two sampling stations (Table 1 ) by Gill nets additional to electroshocking, and fin clip tissue samples having approximate size of $(2 \times 2 \mathrm{~mm})$ were collected from caudal fin / left side of pectoral or pelvic fin without disturbing their morphology. The Size of gene was 1,118 bp for Ompok bimaculatus \& 1,138bp for Clupisoma sinensis. Then this tissue samples were preserved in $100 \%$ ethanol in $1.5 \mathrm{ml}$ micro tubes with appropriate code as tagged on specimens. The fish specimens were preserved in $70 \%$ ethanol. The voucher specimens were collected in Marine Science Centre /Basra University. As well as, the genomic DNA was extracted from ethanol preserved fin clips using C-TAB method (Innis et al., 1989) / DNeasy Blood \& Tissue Kit according to the manufacturer's instructions.

\section{DNA Quantification}

DNA isolated were quantified by using Nanodrop (260/280 ratio). The contamination of samples with RNA or phenolic compounds was detected and samples were processed further for PCR reaction.

Primers for cytb gene were designed using Primer-BLAST from the NCBI database (http://www.ncbi.nlm.nih.gov/tools/primer-blast/) based on sequences available in GenBank were mentioned in (Table 2). Initial PCR amplifications were ran to test the effect of template DNA, dNTPs, Mg++, and Taq DNA polymerase concentrations and to determine the optimum annealing temperature essentially following the method described by Williams et al. (1990) with some modifications in annealing temperature (Williams et al., 1990). Cytochrome b gene was amplified species using specific primers for PCR reactions using Kappa bio systems kit in 96-well plates. The reaction master mix consisted of $9.6 \mu \mathrm{l} 10 \%$ trehalose, $7 \mu \mathrm{l} \mathrm{H2O}, 2.5 \mu \mathrm{l}$ 10X PCR buffer 'B', $0.8 \mu \mathrm{l}$ $\mathrm{MgCl} 2,2 \mu \mathrm{l}$ 2.5mM DNTP, $1 \mu \mathrm{l}$ 10mM forward primer, 1 $\mu \mathrm{l} 10 \mathrm{mM}$ reverse primer and $0.1 \mu \mathrm{l}$ taq polymerase $(5$ units). The PCR reaction profile was comprised of an initial step of $3 \mathrm{~min}$ at $95^{\circ} \mathrm{C}$ and 35 cycles of 30 secs at $94^{\circ} \mathrm{C}$ denaturation, 30 secs at $(51-48)^{\circ} \mathrm{C}$ annealing range for both species, and 30 secs at $72^{\circ} \mathrm{C}$ extension stage, with a final extension at $72^{\circ} \mathrm{C}$ for $10 \mathrm{~min}$. Amplicons were visualized on $2 \%$ agarose gel. The PCR products were purified using Wizard ${ }^{\circledR}$ SV Gel and a PCR Clean-Up System by PR omega (Promega Madison, WI). Sequencing reactions used PCR forward and reverse primers using the Big Dye Terminator v.3.1 Cycle Sequencing Kit (Applied Bio systems, Inc.), finally the purified PCR product was sequenced on an ABI 3130 Genetic analyzer capillary sequencer. Barcode product was paired-end sequencing sequenced to aid full length barcode sequence by avoiding problems in signal deterioration that often occur near the end of a read.

\section{Sequence Analysis}

Sequence polymorphisms were deduced from sequence comparisons in Alignment Explorer (Molecular Evolutionary Genetics Analysis software). Haplotypes and haplotype frequencies were determined within each (cytb) gene individual using DnaSPv5.10 (Khlestkina et al., 2004) and Arlequin v3.1 (Hackauf \& Wehling, 2002), respectively.

\section{Data Analysis}

Sequences were edited using the UPGMA method in MEGA7 (Kumar et al., 2016) and aligned with Clustal W 1.6, implemented in the same software, molecular diversity indices [number of haplotypes, haplotype diversity $(\mathrm{Hd})$ and nucleotide diversities $(\pi)$ ] in order to reveal the level of genetic variation (Schneider et al., 2000). Analysis of molecular variance used to reveal the genetic variation (AMOVA) (Excoffier et al., 1992).

Table 1. List of specimens collected from two sampling stations of Tigris River

\begin{tabular}{lccc} 
Species of samples & Impound & Samarra Dam & Shatt Al- Arab \\
\hline Ompok bimaculatus & Tigris river & 20 & 20 \\
Clupisoma sinensis & Tigris river & 20 & 20 \\
\hline
\end{tabular}

Table 2. List of primers designed for PCR and sequencing of cytochrome b gene

\begin{tabular}{lllr} 
Species Name & Primer & Source & Sequence (5' - 3) \\
\hline Ompok bimaculatus & OB_f1 & NCBI- FJ711312.1 & CACATCTGCCGAGACGTAAA \\
Clupisoma sinensis & OB_r1 & NCBI- FJ711312.1 & AAGGACGTATCCGACGAATG \\
& CS_f1 & JN020088.1 NCBI- & TTACCTTCCGACCACTGACC \\
\hline
\end{tabular}




\section{Results}

The present study reveals low genetic variation within both populations in Shatt Al-Arab location, for Samarra Dam population low genetic variation within Ompok bimaculatus population and no genetic variation within (Clupisoma sinensis) population. According to an analysis of molecular variance of cytb gene for Ompok bimaculatus species, analyses of nucleotide and haplotype diversity were performed separately for each population for Ompok bimaculatus species using the software DnaSP v5.10. Low of the genetic variation was found between individuals within Shatt Al-Arab population and within Samarra dam population where haplotype frequencies varied markedly between the individuals cytb genes were dominated by (3) haplotypes while the haplotype frequencies between genes of Samarra Dam individuals was only (2) haplotypes. Nucleotide and haplotype diversity of Ompok bimaculatus cytb genes were low with range values $\pi=(0.6 \pm 0.1)$ and $\mathrm{Hd}=(0.12 \pm 0.02)$, respectively in Shatt Al-Arab population also within Samarra Dam population the nucleotide and haplotype diversity had reduced, the values of $\mathrm{pi}(\pi)$ ranged around $0.4 \pm 0.1 \times 10$ 3 and $(\mathrm{Hd})$ ranged of $0.11 \pm 0.03$.

The second species (Clupisoma sinensis ) haplotype frequencies varied markedly between the individuals cytb genes of Shatt Al-Arab were dominated by (2) haplotypes but the haplotype frequencies between genes of Samarra Dam individuals was only one haplotype where low genetic variation was found between individuals within Shatt Al-Arab population, nucleotide and haplotype diversity of Clupisoma sinensis cytb genes were low with range values $\pi(0.3 \pm 0.1 \times 10$ $3)$ and $\mathrm{Hd}$ ( ( $0.10 \pm 0.04)$, respectively while no genetic variation noted of Samarra Dam individuals. The mean genetic distance between the observed groups was (0.01823) and (0.01915) of (Clupisoma sinensis) and (Ompok bimaculatus) respectively of Shatt al-Arab species, and the average genetic distance between (Ompok bimaculatus) in Samarra Dam (0.01878), thus There is less genetic variation among individuals, as reported in Table 3.The genetic diversity of Clupisoma sinensis and Ompok bimaculatus from Samarra Dam and
Shatt Al-Arab belonging Tigris River were observed in means of haplotype diversity and nucleotide diversity. The molecular variance analysis (AMOVA) revealed a low genetic variation among individuals within the population sample in the Shatt al-Arab River for both species, but the genetic variance was low only in the Samarra Dam, and there was no genetic variation among the population of Ompok bimaculatus within the population of Clupisoma sinensis. UPGMA Dendrogram based on cytb gene sequences shows that two different clusters of Ompok bimaculatus in Samarra Dam population were formed and three different clusters in Shatt Al-Arab were formed (Figure 2), while two different clusters of Clupisoma sinensis in Shatt Al-Arab population were formed, see Figure 3 . The main findings of this study are as follows:

- Study reveals genetic variation within two populations in two locations using cytb gene.

- Samarra Dam in middle of Iraq did not affect genetic diversity on southern of Iraq as expectation.

- Genetic diversity of Clupisoma sinensis \& Ompok bimaculatus from Samarra Dam \& Shatt Al-Arab belonging Tigris river observed in means of haplotype diversity \& nucleotide diversity.

\section{Discussion}

The genetic variation of Clupisoma sinensis was not observed within species from Samarra Dam population where Data was inferred from mtDNA cytochrome $b$ gene sequences analysis. The nucleotide and haplotype diversity values revealed low genetic variation of $(O$. bimaculatus) and (C. sinensis) populations in Shatt AlArab river southern of Iraq where three haplotypes for Ompok $s p$ and two haplotypes for Clupisoma $s p$. were revealed in spite of the expectation that the dam will affect the genetic diversity, compared with a Samarra Dam populations where pi $(\pi)$ and $\mathrm{Hd}$ values revealed low genetic variation in (O. bimaculatus) population where two haplotypes for Ompok sp.

Haplotype sharing and low nucleotide mutation within both populations was apparent from the data. Based on their low genetic variability and negative

Table 3. Species, population name, number of examined individuals, haplotype and nucleotide diversities and number of haplotypes in each population

\begin{tabular}{lcccccc} 
Species & $\begin{array}{c}\text { Population } \\
\text { name }\end{array}$ & $\begin{array}{c}\text { Examined } \\
\text { individuals }\end{array}$ & $\begin{array}{c}\text { Haplotype } \\
\text { diversity }(\mathrm{h})\end{array}$ & $\begin{array}{c}\text { Nucleotide diversity } \\
(\pi) \pi \pm \mathrm{SD} \times 10^{-3}\end{array}$ & $\begin{array}{c}\text { Haplotypes } \\
\text { Mean genetic } \\
\text { distances }\end{array}$ \\
\hline Ompok bimaculatus & Samarra Dam & 20 & $(0.11 \pm 0.03)$ & $(0.4 \pm 0.1)$ & 2 & $(0.01878)$ \\
Ompok bimaculatus & Shatt Al-Arab & 20 & $(0.12 \pm 0.02)$ & $(0.6 \pm 0.1)$ & 3 & $(0.01915)$ \\
Clupisoma sinensis & Shatt Al-Arab & 20 & $(0.10 \pm 0.04)$ & $(0.3 \pm 0.1)$ & 2 & $(0.01823)$
\end{tabular}




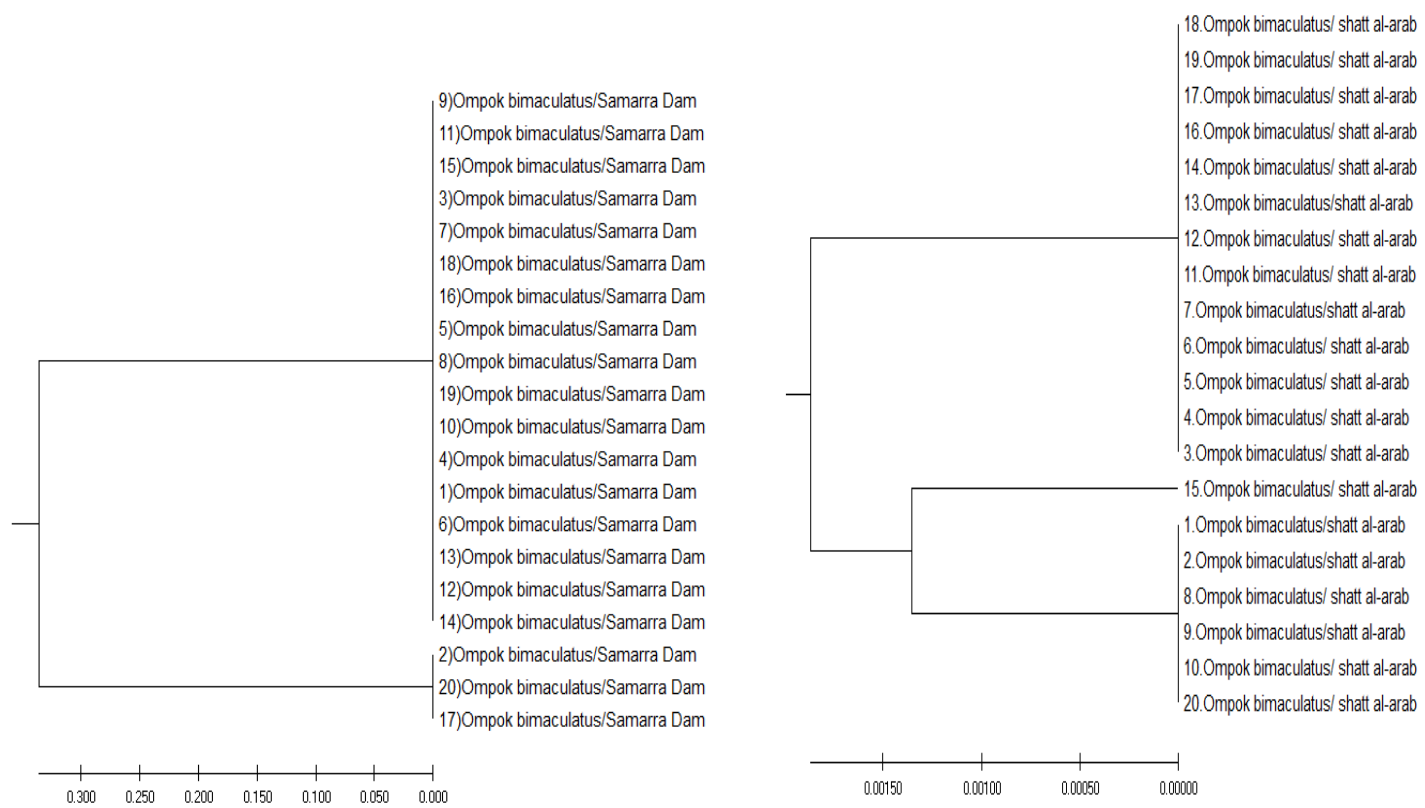

Figure 2. UPGMA Dendrogram, based on the nucleotide divergence (Left: showing the relationship between the Shatt Al-Arab population of Ompok bimaculutus), (Right: showing the relationship between the Samarra Dam population of Ompok bimaculutus).

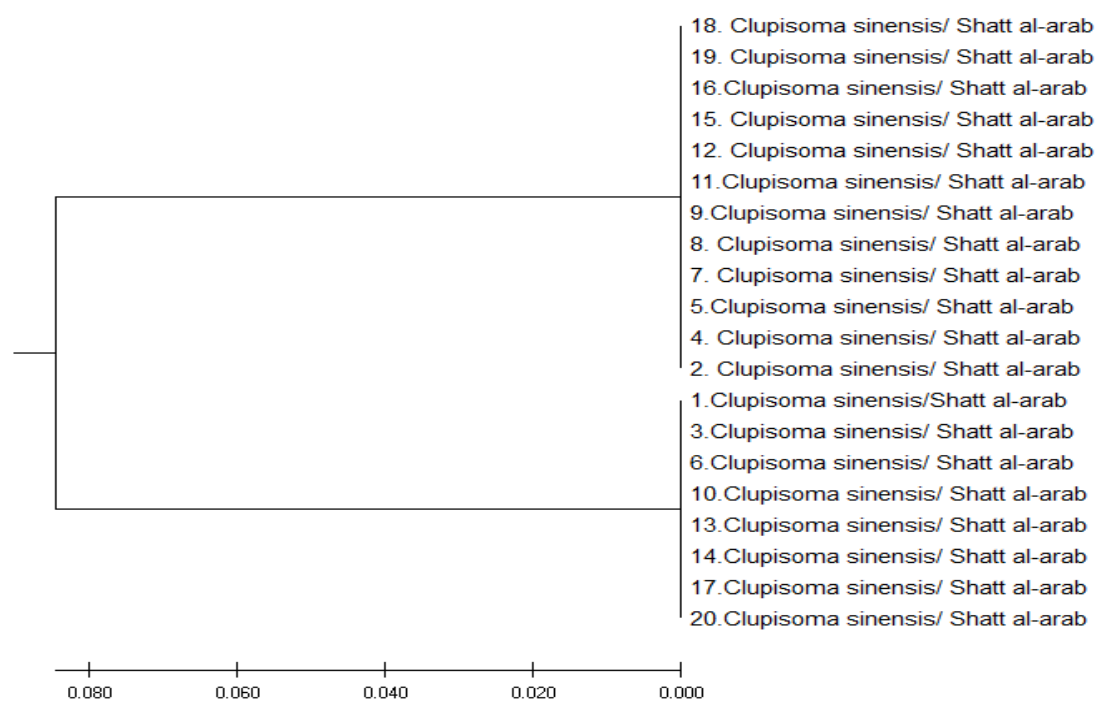

Figure 3. UPGMA Dendrogram, based on the nucleotide divergence showing the relationship between the Shatt Al-Arab populations of Clupisoma sinensis.

contribution towards genetic variation in Shatt Al-Arab region, Overall, this study provided relevant genetic information for planning management, conservation and ranching guidelines for Ompok bimaculatus and Clupisoma sinensis Fishes in Tigris river of middle and south of Iraq.

\section{Conclusion}

Samarra Dam in middle of Iraq did not affect genetic diversity as expectation where low genetic variation was found between individuals within both $(O$. bimaculatus \& Clupisoma sinensis) populations in Shatt Al-Arab River 
southern of Iraq. On the other hand, low genetic variation was found between individuals within $O$. bimaculatus species but no genetic variation within Clupisoma sinensis population in Samarra Dam on Tigris River for several reasons, the most important of which are;

That Shatt Al-Arab is formed by the confluence of the Euphrates river and the Tigris river southern of Iraq where Euphrates river flow by/through Turkey then Syria and by Iraq into the Arabian Gulf through Shatt AlArab.

Our study showed that wild stocks of both species in Shatt Al-Arab and Samarra dam locations must represent a diversified genetic management practices, such as preventing the wanton capture of fish and creating sanctuaries for protecting small stocks which help maintain and conserve the present diverse gene pool even to prevent the resulting in genetic deterioration that subsequently cause a negative impact on aquaculture production where the strict implementations of correct management practices are essential to maintaining the genetic diversity of the natural stocks.

There is also an important conclusion that the best scenario is to reveal the total genetic variation before genetically contaminate.

A further important point is that breeding between two genetically discreet or distant populations may have a positive impact on aquaculture production where one reason of the low genetic variation in Southern of Iraqi water (Shatt Al-Arab)is the alien species on the Iraqi aquatic environment coming from the Euphrates River stretching from Syria to the Shatt al-Arab in southern Iraq out of control recently which is one of current problems were effect to the local stock population were lead to not reveal the total genetic variation before genetically contaminate.

An important point is that breeding between two genetically discreet or distant populations may have a positive impact on aquaculture production where one reason of the low genetic variation in Southern of Iraqi water (Shatt Al-Arab) is the importation of fingerlings and small-scale fish and others of the economic fish species from other countries by breeders and fish farmers.

\section{Acknowledgments}

For Basra University / Marine Science Center for their excellent assistance.

\section{References}

Alberts B., Johnson A., Lewis J. (2002). Molecular Biology of the Cell, 4th Edn New York, NY: Garland Science.

Arab Union of Electricity (2012). "Electrical Power Stations in Iraq" (PDF).

Excoffier, L., Smouse, P.E., \& Quattro, J.M (1992). Analysis of molecular variance.
Feil, R., \& Fraga, M. F. (2012). Epigenetics and the environment: emerging patterns and implications. Nat. Rev. Genet. 13, 97-109. doi: 10.1038/nrg3142

Futuyma, D.J (1998). Evolutionary Biology. Sunderland, MA: Sinauer Associates.

Gould, J.L., \& William, T. K (1996). Carol Grant Gould. Biological Science,6th ed. New York: W. W. Norton \& Company.

Hackauf, B., \& Wehling, P. (2002). Identification of microsatellite polymorphisms in an expressed portion of the rye genome. Plant Breed.; 121(1):17-25. doi: 10.1046/j.1439-0523.2002.00649.x.

Helena, C. (1989). Biology. New York: Worth Publishers.

Innis, M.A., Gelfand, D.H., \& White, T.J. (1989). Edited Book \& Holland, H. J., Innis, M.A. Browse book content. Pages 169-176. Select 22 - RECOMBINANT PCR. Book chapter Full text access. Steven B. Lee and John W. Taylor. Pages 282-287.

Iraq: United States Army, Corps of Engineers. 6 June 2003. Retrieved 27 February (2012). "Iraqi Dam Assessments" (PDF).

Iwasaki, M., \& Paszkowski, J. (2014). Epigenetic memory in plants. EMBO J. 33 1-12. 10.15252/embj.201488883

Khlestkina, E.K., Ma HMT, Pestsova, E.G., Roder, M.S., Malyshev, S.V., Korzun, V., \& Borner, A. (2004). Mapping of 99 new microsatellite-derived loci in rye (Secale cereale L.) including 39 expressed sequence tags. Theor Appl Genet. 2004;109(4):725-732. doi: 10.1007/s00122004-1659-z.

Kumar, S., Stecher, G., \& Tamura, K. (2016). MEGA7: molecular evolutionary genetics analysis version 7.0 for bigger datasets. Mol Biol Evol;33(7):1870-4. View Article PubMed Google.

Lars Feuk, A.R., \& Stephen, W.S. (2006). "Structural variation in the human genome". Nature Reviews Genetics. 7 (2): 85-97. PMID 16418744.

Levenson, J. M., Roth, T. L., Lubin, F. D., Miller, C. A., Huang, I. C., \& Desai, P. (2006). Evidence that DNA (cytosine-5) methyltransferase regulates synaptic plasticity in the hippocampus. J. Biol. Chem. 281, 15763-15773. doi: 10.1074/jbc.M511767200

Meyer, P. (2015). Epigenetic variation and environmental change. J. Exp. Bot. 66 3541-3548. 10.1093/jxb/eru50

Patterson, C. (1999). Evolution, 2nd ed. Ithaca, NY: Comstock. Pavlopoulos, G.A., Oulas, A., lacucci, E., Sifrim, A., Moreau, Y., Schneide, R., Aerts, J., \& Iliopoulos, I. (2013). "Unraveling genomic variation from next generation sequencing data.". BioData Mining. 6 (1): 13. PMC 3726446Freely accessible. PMID 23885890. doi:10.1186/1756-0381-613.

Ridley, M. (1993). Evolution. Boston: Blackwell Scientific.

Robert, L. \& Carroll. (1997). Patterns and Processes of Vertebrate Evolution, Cambridge University Press, pp. 296-97

Sato, F., Tsuchiya, S., Meltzer, S.J., \& Shimizu, K (2011). MicroRNAs and epigenetics. FEBS J; 278:1598-609.

Schneider, S., Roessli, D., \& Excoffier, L. (2000). ARLEQUIN: A Software for Population Genetic Data Analysis. Version 2.000, Genetics and Biometry Laboratory, University of Geneva, Switzerland.

United States Army, Corps of Engineers. 6 June 2003. Retrieved 27 February (2012). _"Iraqi Dam Assessments" (PDF).

Vaillant, I., \& Paszkowski, J. (2007). Role of histone and DNA methylation in gene regulation. Curr. Opin. Plant Biol. 10 528-533. 10.1016/j.pbi.2007.06.008 
Vineis, P., Chatziioannou, A., Cunliffe, V. T., Flanagan, J. M., Hanson, M., \& Kirsch-Volders, M. (2017). Epigenetic memory in response to environmental stressors. FASEB J. 31, 2241-2251. doi: 10.1096/fj.201601059RR.

Wang, H., Wu, J., \& Meng, X (2011). MicroRNA-342 inhibits colorectal cancer cell proliferation and invasion by directly targeting DNA methyltransferase 1. Carcinogenesis; 32:1033-42.
Williams, J.G.K., Kubelik, A.R., Livak K.J., \& Rafalski, J.A (1990). Tingey S.V. DNA polymorphisms amplified by arbitrary primers are useful as genetic markers. Nucleic Acids Res.; 18:6531-6535.

Yan, H., Choi, A.J., Lee, B. H., \& Ting, A. H (2011). Identification and functional analysis of epigenetically silenced microRNAs in colorectal cancer cells. PLoS One ;6: e20628. 